\title{
小麦赤銹病に対するサルファダイアジンの発病抑制効果
}

\author{
第 1 報 小麦子苗による実験結果
}

\section{山田昌 雄*}

Masao YAMADA: The sporulation-inhibitive effects of sulfadiazine on wheat leaf rust. I. Some experimental results with wheat seedlings.

\section{1. 緒言}

或種の sulfonamide 剤が麦類銹病の発生を抑制す ることが，最近 Hassebrauk ${ }^{1,2,3,4)}$ や Hotson $^{5}$ ) に より報告されている。何れも多数の薬猎を試験して, 前者は ladogal (p-aminobenzolsulfonoxymethylamide- $\mathrm{N}^{4}$-d-glucoside sulfonic acid) を選び主とし て小麦赤錗病菌に対する作用を, 又, 後者は sulfadiazine (2-p-aminobenzolsulfonamide-pyrimidin) を 選えで小麦黒銹病菌に対する作用を調べ，それぞれ夏 胞子堆の発生を著しく抑制することを報じている。筆 者は小麦赤錴病に対する sulfadiazine の発病抑制効 果を,主として実用的な価值を検討する意味で調査し， 大体，同様な結果を得ているが，その中，小麦子苗に よる実験結果について報告する。

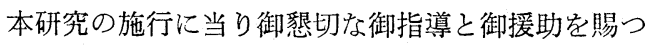
た当試験地八柳技官, 東大農学部明日山教授, 名大農 学部平井教授, 実験材料の入手に御援助を頂き, かつ 御指導を賜つた山之内製薬株式会社専務取䋨役岡田良 太郎氏，同社研究所微生物部長大薗卓氏その他の方々 に厚く感謝の意を表する。又，実験に協力された高橋 幸吉, 高橋広治両氏に深謝する。

\section{2. 実験材料と方法}

日本薬局法の sulfadiazine 結晶は水に溶け難いの で山之内製薬の御好意により，その $\mathrm{Na}$ 塩を作つて 頂いて使用した。（文中 SD と略記）。拮抗作用の実 験に用いた p-amino benzoic acid（交中 PABA と. 略記）览一化学薬品株式会社の製品である。, 又, 薬 剂を噴霧する場合には, 展着, 剂として東京化成 工業株式会社製の Tween-20 (polyoxyethylene sorbitan mono-laurate) を容量 1\% の割合で加え, ク ロマトグラフィー用の小型フトマイザーで噴蓩した。，

小麦品種は農林 16 号又ほ農林 58 号, 菌系は培盖 系統 S 508 (race group 1)7), S 31 (race group 9),

\footnotetext{
* 農林省東北農業試験場盛岡試験地
}

S 24，S 310 (何れも race group 21）の中，いずれか を使用し，感染型6)(4) を生ずべき品種と菌系との組 合せを用いた。，小麦は上端の内径約 $8.5 \mathrm{~cm}$ 深さ約 $7 \mathrm{~cm}$ の素焼鉢に 8〜10 粒播き, 1 処理区に 4 5 鉢

合計約 40 個体として，特に記した場合を除いては 播種後 7〜10 日の幼苗期に brushing method を以 て，充分均一になるように赤銹病菌を接種した。

実験は 1953 年夏より 1954 年夏にわたり,すべて 硝子室内で行つた。

薬剤の効果は各個体の第 1 葉に発生した成熟胞子堆 数をかぞえ，これを各処理区に就て平均し，無処理の 対照区の值を 100 として，これに対する相対的数值を 以て比較した。無処理区及び薬片効果の少ない区では 感染型 (4) の充分に成熟した胞子堆の夕が発生し, 効 果が增すに従い大きな成熟胞子堆は減少し, その代り に裂開はしているが非帯に小さい胞子堆，未成熟な感 じのする胞子堆,ならびに chlorotic な小点が増加し, 遂には軽い chlorotic spots のみになる。この変化は 感染型の $(4) \rightarrow(3) \rightarrow(2) \rightarrow(1) \rightarrow(0)$ という変化ではな くて, むしろ成熟胞子堆 $\longrightarrow$ 未成熟胞子堆 $\rightarrow$ chlorotic spots という方向の変化である。この理由により, 薬 郕効果の測定には感染型を以てせず，上記の如く成熟 胞子堆数により行つたのである。

\section{3. 実跧結果と論議}

\section{（1）鈢土にSD溶液を注いだ場合の効果}

接種後に鉢土に SD 溶液を注いだ場合, 著しい発病抑 制が見られた。実験の1例をあげれば，9月 29 日に 接種し, 27 時間後 50〜 $1000 \mathrm{ppm}$ の濃度の SD 蒸溜 水溶液を 1 鉢 $30 \mathrm{cc}$ ずつ注ぎ, 接種の 10 日後と 15 日後の 2 回, 効果を検した。，対照区では同量の蒸溜水 を注いだ結果は第1表に示される。即ち $200 \mathrm{ppm} の$ 濃度では胞子堆発生は始めは著しく減少したが, 未成 熟胞子堆のような状態のものが漸次裂開して 15 日後 にはかなりの発生を見た。しかし $700 \mathrm{ppm}$ 以上の濃 度では強い抑制力を保つていた。 
Tadle 1. - Effect of sulfadiazine-Na aq. on wheat leaf rust by soil application at the rate of $30 \mathrm{ml}$ per $8.5 \mathrm{~cm}$ pot. (Sulfadiazine was applied 27 hours after inoculation.)

\begin{tabular}{l|c|c|c|c|c|c|c|c}
\hline $\begin{array}{c}\text { Concent- } \\
\text { ration of } \\
\text { solution }\end{array}$ & $\begin{array}{c}\text { Cont- } \\
\text { rol }\end{array}$ & $\begin{array}{c}50 \\
\text { ppm }\end{array}$ & $\begin{array}{c}\prime \prime \\
\text { Time of }\end{array}$ & $\begin{array}{c}200 \\
\text { Time }\end{array}$ & $\begin{array}{c}300 \\
\prime\end{array}$ & $\begin{array}{c}500 \\
\text { observation }\end{array}$ & $\begin{array}{c}700 \\
\prime \prime\end{array}$ & 1000 \\
\hline $\begin{array}{c}10 \text { days after } \\
\text { inoculation }\end{array}$ & 100 & 107 & 88 & 41 & 10 & 0 & 0 & 2 \\
\hline $\begin{array}{c}15 \text { days after } \\
\text { inoculation }\end{array}$ & 100 & 98 & 112 & 113 & 79 & 28 & 1 & 13 \\
\hline
\end{tabular}

銶土の表面積は 1 錸約 $50 \mathrm{~cm}^{2}$ であるから,700 ppm 区で桜 $40 \mathrm{mg} / 100 \mathrm{~cm}^{2}$ の施与量に当る。実験を反 復してこの濃度の効果を確め得た。 $500 \mathrm{ppm}$ 以上の濃 度では第 2 葉以上の葉の緑色が全体的に䬶せ, 淡緑色 となる。このことは 700, $1000 \mathrm{ppm}$ では特に著しく 生育も抑制される。この土壤処理の効果に法, 使用し た小麦品種及び菌系統の範囲では差異が認められなか つた。、なお，全体的に極めて高い抑制効果があつた鉢 で1個体のみが対照と変らぬ発病を示した例がしばし ば認められた。

さらに土壤処理の適時に就て次の実験它行つた。7 月 2 日に接種し，その 1 7 日後に SD の $1500 \mathrm{ppm}$

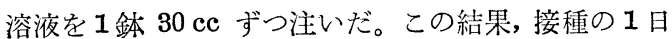
後と 2 日後の処理でほ殆ど完全な抑制効果が示された が，3 日以後は急速に効果が減じ，対照と殆ど変らな かつた。即ち, 感染初期のみに処理の効果があるよう である。

又 $\mathrm{SD}$ の $1500 \mathrm{ppm}$ ，溶液を接種の 1 9 日前に鉢 土に注いだ実験ではすべての処理区で完全な発病抑制 効果が得られた。即ち, この場合 SD の効果は少く も 9 日間は減少することなく維持される。

（2）SD溶液を植物体に晎霜した效果既 に Hassebrauk が指摘しているように2), sulfonamide 剤は土壤中の腐植に強く吸着されるから，これを実用 に供する場合には植物体の地上部より吸収させねばな らない。

植物体に SD 溶液を噴蓩した実験の 1 例を次にあ げる。9 月 8 日に接種し, 約 30 時間後に 50〜 1000 ppm の種々の濃度の.SD 溶液に容量 $1 \%$ の Tween -20を加え， 1 区 4 鉢に対し $20 \mathrm{cc}$ の割合で噴篛し, 12 時間湿室に入れた後，硝子室に置いた。この薬量 で，植物体の表面は充分に濡れ水滴が落ちを状態にな る。対照区は同量の蒸水溜を噴霧し, 又 Tween-20の みの $1 \%$ 溶液を噴罞した区をも設けた。接種の 9 日
後と 14 日後に検した結果沙第 2 表に示される。

Table 2.—Effect of sulfadiazine-Na aq. on wheat leaf rust by spraying at the rate of $5 \mathrm{ml}$ plus 1 per cent Tween-20 per $8.5 \mathrm{~cm}$ pot. (Sulfadiazine was applied 30 hours after inoculation.)

\begin{tabular}{|c|c|c|c|c|c|c|c|c|c|}
\hline $\begin{array}{l}\begin{array}{l}\text { Concent- } \\
\text { ration of } \\
\text { solution }\end{array} \\
\text { Time of } \\
\text { obser- } \\
\text { vation }\end{array}$ & \begin{tabular}{|l|} 
\\
Cont \\
rol
\end{tabular} & $\left|\begin{array}{c}\text { Cont- } \\
\text { roil } \\
+ \\
\text { Twe- } \\
\text { en-2) }\end{array}\right|$ & $\begin{array}{l}50 \\
\prime \prime\end{array}$ & $\begin{array}{c}100 \\
\prime \prime\end{array}$ & $\begin{array}{c}200 \\
\prime \prime\end{array}$ & $\begin{array}{c}300 \\
\prime \prime\end{array}$ & $\begin{array}{c}500 \\
\prime \prime\end{array}$ & $\begin{array}{c}700 \\
\prime \prime\end{array}$ & $\begin{array}{c}1000 \\
\prime \prime\end{array}$ \\
\hline $\begin{array}{l}9 \text { days after } \\
\text { inoculation }\end{array}$ & 100 & 143 & 98 & 61 & 58 & 47 & 32 & 30 & 9 \\
\hline $\begin{array}{l}\text { 14days after } \\
\text { inoculation }\end{array}$ & 100 & 130 & 115 & 102 & 88 & 81 & 88 & 89 & 74 \\
\hline
\end{tabular}

この試験では接種 9 日後の観察では高濃度液の場合 にかなりの抑制効果が示されたが，その後 5 日の中に 対照と大差ないまでに胞子堆の発生を見た。，即ち，こ の程度の SD 処理では胞子堆の成熟が遅延するだけ

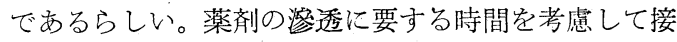
種 5 日前と 2 日前の 2 回に同様な処理を行つた場合に も結果注同じであつた。，展着郕として「改良リノー」 を用いた別の実験では $1750 \mathrm{ppm}$ といら高濃度でも 発生が遅れたら゙けであつた。薬害は $1000 \mathrm{ppm}$ 程度 までは殆ど認められなかつたが，これより濃くなると 土壤処理の場合と同様な影響が見られた。

sulfonamide 剂を植物体に噴霧する場合に，Hassebrauk $^{2}$ は ladogal の $3 \%$ 水溶液を充分に用いた 場合にも小麦赤銹病を完全には抑制し得なかつた。し かし Hotson ${ }^{5}$ ) は最低 200 ppm の濃度の sulfadiazine の溶液で小麦黒銹病を完全に抑制し得たと報じてい る。筆者の実験では同じ展着剤を用いて $1000 \mathrm{ppm} の$ 溶液を以てしてもなお抑制し得なかつた。これは病原 菌の相異によるものであろうが, 展着, 遪透を助ける ための補助剤については更に研究を要するであろ.う。

先に述べたように子苗に就ての実験では，高い発病 抑制効果を得る濃度では，同時に葉の能色，生長抑制 等の有害な副作用が観察されたが，苗龄が進さに従い 軽減される傾向があるから，固場で生育した植物体に 対して以副作用無く有効量の薬郕を与え得ることが期 待される。

(3) SD 己 PABA との拮抗作用各種細菌 に就て sulfonamide 剂と $\mathrm{p}$-amino benzoic acid と の拮抗作用が認められ, sulfonamide 剂の作用機構も この事実に基づいて説明されているが, ladogal の小 麦赤銹病菌に対す当作用, sulfadiazine の小麦黒銹病 
菌に対する作用も， p-amino benzoic acid によつて 拮抗される事がそれぞれ証明されている3,5)。SD の赤 銹に対する作用にも同様なととが次の実験によつて認 められた。10 月 12 日に接種し，14 日に SD の 500 $\mathrm{ppm}$ 溶液を 1 鉢 $30 \mathrm{cc}$ ずつ注ぎ， 24〜84 時間後に PABA の $1000 \mathrm{ppm}$ 溶液を 1 区 5 釷に $30 \mathrm{cc}$ ずつ噴 霧した。10月 29 日観察した結果は第 3 表の通りで

Table 3.-Counteracting effect of p-amino benzoic acid spraying* on the soil application of sulfadiazine.**(Sulfadiazine was applied 2 days after inoculation.)

\begin{tabular}{|c|c|c|c|c|c|c|c|}
\hline \multirow{2}{*}{ Control } & \multirow{2}{*}{$\begin{array}{l}\text { SD } \\
\text { only }\end{array}$} & \multicolumn{6}{|c|}{$\begin{array}{l}\text { Interval between SD appli- } \\
\text { cation and PABA spraying }\end{array}$} \\
\hline & & $\begin{array}{c}24 \\
\text { hours }\end{array}$ & $\begin{array}{l}36 \\
\prime \prime\end{array}$ & $\begin{array}{l}48 \\
\prime \prime\end{array}$ & $\begin{array}{l}60 \\
\prime \prime\end{array}$ & $\begin{array}{l}72 \\
\prime \prime\end{array}$ & $\begin{array}{c}84 \\
\prime \prime\end{array}$ \\
\hline 10 & 38 & 87 & 78 & 73 & 91 & 93 & 81 \\
\hline
\end{tabular}

* PABA rate: $6 \mathrm{ml}$ per $8.5 \mathrm{~cm}$ pot

** SD rate: $30 \mathrm{ml}$ per $8.5 \mathrm{~cm}$ pot

あつた。この実験は PABA の作用を明らかにさせる ため, SD は $500 \mathrm{ppm}$ といら低濃度液を用いたので 対照区でも或程度の高い羅病度を示し， SD̉ の抑制効 果が低かつたことがわかる。，しかし，PABA の处理 区ではすべてに高い睢病度が示され，拮抗作用が明ら が認められる。PABA 溶液を土壤に注いで行つた， 同椂の実験ではすべての処理区で胞子堆の発生が強く 抑制された。即ち, この場合には PABA の効果は認 められなかつた。Hassebrauk ${ }^{3}$ の報告では, PABA を土壤から吸収させた場合に， sulfonamide 剂との 拮抗作用は両者の量的関係が適当であれば吸収の時間 的関係江支配される。即ち, 先に作用したもの小効果 が大きく現れることが示されているが，筆者の実験で 葉面より PABA を供給した時には SD 土壤処理の 3 日後にも効果が表れ，土壤に PABA を供給した時に は SD 处理の 24 時間後でも無効であつたことは,
SD が根から速やかに吸収されるのに対し，PABA は 比較的吸収され難く, 葉面よりの吸収はこれとは逆に PABA の方が SD よりも速いのであるうと考光られ る。その他の点では前記両者の実験結果とよく一致し その見解を支持する。

\section{4. 摘 要}

（1）小麦赤鉟病菌に対する sulfadiazine の作用 を硝子室内で小麦子苗に就て検した。

（2）小麦子苗に対し赤銹病菌を接種した後に sulfadiazine の $\mathrm{Na}$ 塩を水溶液として錸土の表面に約 $40 \mathrm{mg} / 100 \mathrm{~cm}^{2}$ 以上与元た場合に夏胞子堆の発生を著 しく抑制したが，葉の螁色，生長の抑制等の副作用が 観察された。この処理は接種後 2 日以内に行つた場合 にのタ効果がある。又，接種前にこの方法で処理した 場合, その効果は少くも 9 日間減少せずに維持される。

(3) - 薬液に Tween-20 を加えて小麦子苗に噴霧 した場合には，一旦，発病は抑制されるが，後漸次発 病して土壤処理に比して効果は極めて低かつた。

(4) sulfadiazine の赤銹病抑制効果は p-amino benzoic acid により消去される。

(1955 年 2 月 19 日受理)

\section{引用文献}

1. Hassebrauk, K.: Phytopath. Z., 17: 384 400. (1951).

2. — Ibid., 18: 453 460. (1952).

3. —: Ibid., 19: 56 78. (1952).

4. — : Ibid., 21: 218 220. (1953).

5. Hotson, H. H.: Phytopath., 43: 659 662. (1953).

6. Mains, E, B. \& Jackson, H. S.: Phytopath., 16: 89 120. (1926).

7. 山田昌雄：農業技術, 8：273～274. (1953).

\section{Summary}

The effects of sulfadiazine on the infection of wheat seedlings by leaf rust, Puccinia triticina, were examined.

The development of uredosori on seedlings of the highly susceptible wheat varieties is remarkably inhibited by soil application of sulfadiazine$\mathrm{Na}$ salt aq. at the rate of $40 \mathrm{mg}$ per $100 \mathrm{sq} . \mathrm{cm}$ within 2 days after inoculation. With delay in application of the sulfadrug, rust-inhibitive effect decreased rapidly. Phytotoxic secondary effects, i. e. stunting of the plants and chlorosis of the leaves, were fairy marked at the effectual dosage.
The effect of application before inoculation is well maintained for at least 9 days.

When wheat seedlings are sprayed to "run off" with the preparation up to a concentration of 1000 ppm plus 1 per cent Tween-20 as a wetting agent, the development of sori is inhibited for some periods, but later on resumed gradually, the effect is very poor compared with that of soil application.

The rust-inhibitive effects of sulfadiazine are conteracted by the supply of p-amino benzoic acid. 